\title{
Ecosystem Services of Vegetation Features as the Multifunction Anti-Erosion Measures in the Czech Republic in 2019 and Its 30-Year Prediction
}

\author{
Marie Balková ${ }^{1, * \mathbb{D}}$, Lucie Kubalíková ${ }^{1}$, Marcela Prokopová ${ }^{2}$, Petr Sedlák ${ }^{3}$ and Aleš Bajer ${ }^{1}$ \\ 1 Department of Geology and Soil Science, Faculty of Forestry and Wood Technology, Mendel University in \\ Brno, 61300 Brno, Czech Republic; lucie.kubalikova@mendelu.cz (L.K.); ales.bajer@mendelu.cz (A.B.) \\ 2 Global Change Research Institute of the Czech Academy of Sciences, Lipová 1789, 37005 České Budějovice, \\ Czech Republic; prokopova.m@czechglobe.cz \\ 3 Department of Forest Protection and Wildlife Management, Faculty of Forestry and Wood Technology, \\ Mendel University in Brno, 61300 Brno, Czech Republic; petr.sedlak@mendelu.cz \\ * Correspondence: marie.balkova@mendelu.cz; Tel.: +420-545-134-040
}

check for updates

Citation: Balková, M.; Kubalíková, L.; Prokopová, M.; Sedlák, P.; Bajer, A. Ecosystem Services of Vegetation Features as the Multifunction Anti-Erosion Measures in the Czech Republic in 2019 and Its 30-Year Prediction. Agriculture 2021, 11, 105. https: / / doi.org/10.3390/

agriculture11020105

Academic Editor:

José Alfonso Gómez

Received: 3 December 2020

Accepted: 25 January 2021

Published: 28 January 2021

Publisher's Note: MDPI stays neutral with regard to jurisdictional claims in published maps and institutional affiliations.

Copyright: (c) 2021 by the authors. Licensee MDPI, Basel, Switzerland. This article is an open access article distributed under the terms and conditions of the Creative Commons Attribution (CC BY) license (https:/ / creativecommons.org/licenses/by/ $4.0 /)$.

\begin{abstract}
The communication presents the pieces of information of the ecosystem services estimation of the four research localities transformed from an arable land to vegetation features-bosks. These bosks should dispose several ecological functions, primarily anti-erosion measures, additionally the local biodiversity increase, unfavorable microclimate mitigation, shelter provision for small game, birds and insects, or wood and fruit production, etc. One of these benefits, the biodiversity increase, can be evaluated using the Habitat Valuation Method (HVM) and expressed by the financial value obtained on the basis of a combination of expert valuation and cost replacement method. The various combinations of local woody plants and bushes within the project Multifunction anti-erosion measures as a part of adaptable landscape were planted or sown at the project localities (South Moravia and Žd'árské vrchy, Czech Republic) in March 2019. Ecosystem services evaluation was one of the fundamental outcomes of the project. The most important result was the calculated value increase of the service termed "environment for the species life providing and genetic diversity conserving". The increase means the difference between the state prior to planting and the expected target state after 30 years as specified in HVM. In total, the increase of this ecosystem service of the four bosks was valued at 2,633,809.64 CZK (97,206.48 EUR/114,399.06 USD).
\end{abstract}

Keywords: anti-erosion measures; bosks; ecosystem services; erosion; vegetation; woody plants

\section{Introduction}

The landscape value increase in the sense of ecosystem services provision is the topical key issue for conserving its natural functions needed, especially in disturbed areas with very intensive human activities [1-4]. Unfortunately, the disturbances which are caused by natural processes and directed in accordance with the principles of nature, are omitted. In this study, the main issue is the disruption of these natural processes, caused by intensive interventions, which have fundamentally influenced and altered the environment into the visual aspect and form that neither visually nor remotely resemble the original state at all.

Specifically, in this case, the problem was caused by original natural habitats transformation into arable land, with contemporary intensive conventional agricultural management [5]. Such management generates lots of problems [6] and complications, including huge decrease in its environmental functions that are limited only to production in fact, other ecological functions are almost completely suppressed. This is a typical example of ecosystem services trade-off where intensification of agriculture and promotion of solely production services cause a significant decrease of the other groups of services including regulating (erosion protection, climate regulation, and water retention), supporting (habitat provision) or cultural ones (land use character and esthetics) [7]. Other resulting problems 
are significant suppression in biodiversity [8-11], water retention capacity reduction [12], rise of undesirable elements from agricultural fertilizers in the soil [13,14], etc. Almost all of these facts result in bad coherence of soil particles and thus in easier erodibility and huge organic matter loss from widespread arable land areas [15-17]. This is largely because the arable land is usually managed in areas of several tens of hectares, where the risk arises even in areas smaller than a hectare. The second unfavorable factor is the fact that almost for the entire year, a very large area of arable land is uncovered by crops, especially concerning broad-leaved crops and due to early harvest [18]. This phenomenon (large blocks of monocultures and unsuitable management) is typical for countries in Central Europe (mainly Czech Republic, Slovakia, Poland, or Hungary) as a remain of the intensive agriculture during the 1950-1990 Soviet era [19], compared to Austria with agriculture based on small arable land blocks and diversity of cultivated crops as an example [20].

All the aspects mentioned above lead to unacceptable loose of soil matter [10,21-24]. This can be mitigated by division of arable land blocks by specific anti-erosion measures as an example. The greatest service for both arable land and the surrounding landscape systems can probably be provided by any vegetation feature, incorporated into large blocks of crop monocultures [5,25-30]. In fact, we can talk about the whole farmland also including meadows and pastures, very frequently managed in a monoculture mode.

\subsection{Project Introduction}

This issue of erosion and problems related were involved within the project of Multifunction anti-erosion measures as a part of adaptable landscape, which deals with planting and seeding vegetation features as the important part of the landscape providing a wide scale of ecological functions. The main goal of the project was testing an alternative way of vegetation features estimation consisting in seeding-the most natural, yet underestimated way of growing plants. Also, seeding can be considered as a unique way in the Central European space (characterized as the area of temperate deciduous forest). The great advantages are little costs for the sowing material and consequent care about such vegetation features as well as healthy and stable stands thanks to the possibility of adaptation to the ecological conditions of the habitat from the seed phase. There were also other secondary project goals, and as one of them, we would like to present the results of habitat benefits evaluation, that was scheduled as one of the project results. Within the research ongoing on the four localities in South Moravia and Žd'árské vrchy (Section 2.1), thus vegetation features were planted as the parts of farmland blocks. The conditions for this choice were mainly the following ones: Locality could be incorporated within the large block of arable land and was under erosion threat, cooperation with owners and their will and agreement with the experiment, previous experience with vegetation planting in the region and feasibility of the experiment consisting in sowing and presumption of its positive effect. These features were created by sowing or planting mixture of native forest trees and bushes with flowery meadow added in the places. The woody species were selected so that there are not only species of natural composition of each specific locality, but also honey-bearing or fruiting species as a source of birds' food. More detailed information about particular localities is described in Section 2.1.

\subsection{The Aim of the Study}

The aim of this study was ecosystem services evaluation as one of the projects outcomes. All four localities (Section 2.1) were evaluated in the state before planting (2019), and their expected economic benefit after 30 years as this period is pre-modeled in HVM [1] as the time presumed to be necessary to reach their full possible stability and complex of ecological functions, services, and benefits. The economic benefits are expressed by value increase calculation of the service environment for the species life providing and genetic diversity conserving. A comparison of the results between the localities is an integral part of the study, as it is discussed and justified, as well as the possible future development and 
its impact on possible deviations from the expected state. This method (or its previous versions) has been used in several studies in the Czech Republic [31-34].

\subsection{Bosks}

Vegetation feature is a quite wide term used for several types of landscape vegetation (or non-forest woody greenery). This report deals with both linear and irregular shapes of woody vegetation planted on arable land specified below. Unfortunately, in English, there is no exact equivalent for this kind of the feature. The authors chose "bosks" as the most appropriate term (other variants are, for instance, bosques, hedgerows, groves, clusters, and niches) [35].

In general, a bosk is a vegetation feature in the open landscape composed of lower woody plants, bushes, and herbs. It could be of a linear shape, because of being a part of field margins, that historically divide particular parcels. Sometimes we can observe any other irregular shapes, like one of the localities in this study. However, this phenomenon has been disrupted on the major area of the Czech Republic as the bosks and field margins were plowed up to become a part of widespread farmland complexes during the Soviet era (1950-1990) [19,36], compared, e.g., to Austria [20], bosks are not a common part of Czech agricultural landscape. This way, we return to the basic of the topic and to the reason for bosks as our choice of suitable anti-erosion measurement. At the same time, the bosk brings other functions and services to the landscape like more favorable microclimate, food for small game and birds, and shelter for game [37]. Other significant functions are represented by filtration of substances entering the air and soil, windbreak, or the aesthetic aspect in the landscape. The bosk should also have a production function as a source of wood, in the case of blooming woody plants and herbs also as a source of pollen and nectar for honey production, as well as the choice to medicinal herbs collection, etc. [38]. In comparison with hedgerows (the name is used mainly in France or Great Britain [39,40]), bosks could be of any shape (as hedgerow is usually linear feature dividing particular parcels), could provide more ecosystem services as they are sometimes planted by gamekeepers primarily to be a refuge for small game and birds or for the reasons described above [37].

From the legislative point of view [38], planting and caring for bosks is a part of hunting grounds users' duties (Paragraph 11, Section 1 of Act No. 449/2001 Coll./§) [41]. If the bosk is defined only according to valid legislative, it is impossible to describe its whole principle, because the legislative definition is too narrow [38]. The best definition is anchored in the Government Regulation No. 307/2014 Coll. [42], where the bosk is included in field margins as "a continuous line-type formation, used mainly to reduce the risk of water or wind erosion, usually delimiting the boundary of arable land blocks; woody vegetation, a stone wall or a grassy area can be a part of such a field margin" (Paragraph 5, Section 4 of Government Decree No. 307/2014 Coll. [43]). In other laws, this feature is mentioned quite marginally, e.g., as one of the forms of an Important Landscape Element, or as a part of Territorial System of Landscape Ecological Stability or anti-erosion measure [38,43]. The bosk planting has been financially supported by European funding, namely European Structural and Investment Funds $[44,45]$ or national funding, e.g., Landscape Care Program [46] or The Landscape Natural Function Restoration Program [47].

\subsection{ConceptualBackground of Ecosystem Services and theirEvaluation}

Ecosystem services are the benefits (goods and services) that society obtains from nature [48]. Costanza et al. [49] define ecosystem services (ES) as "the ecological characteristics, functions, or processes that directly or indirectly contribute to human wellbeing". The concept of ecosystem services gradually developed in the second half of the 20th century [49-51], for an overview of the development of the concept, see Braat and de Groot [52] or Costanza et al. [49], but the Millennium Ecosystem Assessment (MEA) [48] is considered to be a basic document where the definitions and approaches were presented together with justifications why further developing of the concept of ecosystem services was necessary. 
These days, this concept has already been fully accepted as an important base for nature conservation, landscape planning, responsible, and sustainable use of resources within different types of ecosystems as proven by numerous papers and monographies [49,5355]. The assessment of ecosystem services is considered as a base for their quantification and environmental accounting [56,57] and references herein and as an important issue in land-use policy [58,59]. There are numerous classifications of ecosystem services for various purposes. Primarily, the classifications come from the MEA classification [48]. Several authors discussed these topics and problems of classification [60-62], numerous authors proposed classification for scientific analysis, economic valuation, and policymaking [56,63,64], for overview see an editorial of Burkhardt et al. [65]. Recently, Common International Classification of Ecosystem Services (CICES) has been developed, and it includes both biotic and abiotic ecosystem services. This classification was established by European Environmental Agency (EEA) to unify the ecosystem services for environmental accounting [66]. In the Czech Republic, the classification and methodology by Frélichová et al. [67] is used (respectively Vačkář et al. [68]—-methodology in Czech).

Ecosystem services are traditionally divided into four groups: Provisioning, regulating, cultural, and supporting [48].

- Supporting services are represented by basic ecosystem processes, such as soil formation, primary productivity, nutrient cycling, biogeochemistry, and provisioning of habitat (or according to Costanza et al. [63] refugia service). They contribute to the human wellbeing indirectly via affecting other types of services-provisioning, regulating and cultural ones [48,63].

- Provisioning services are the products obtained from ecosystems, including, for example, genetic resources, food and fiber, and fresh water [48]. De Groot et al. [69] distinguish the use of biotic resources (i.e., products from living plants and animals) and abiotic resources (mainly sub-surface minerals). The biotic resources have always been considered and rather emphasized, but in the recent years, the importance of abiotic resources is also recognized [70-72].

- Regulating services are the benefits obtained from the regulation of ecosystem processes, e.g., climate regulation, water regulation, pests and disease regulation [48]. According to de Groot et al. [69] these services are essential to human existence on the Earth. However, as they customarily have indirect benefits, they are not frequently recognized until they are lost or disturbed [69].

- Cultural values of ecosystems are as important as other services for many local communities [48]. People have benefited in many ways from cultural ecosystem services, including aesthetic enjoyment, recreation, artistic and spiritual fulfillment, and intellectual development [73]. Generally, the cultural ecosystem services can be defined as nonmaterial benefits people obtain from ecosystems through spiritual enrichment, cognitive development, reflection, recreation, and aesthetic experiences [48]. The conceptual and methodological aspects of cultural ecosystem services were discussed in numerous papers [69-80].

\section{Materials and Methods}

The four evaluated localities are placed at the exposed habitats predominantly from the point of view of erosion soil loss and all the related problems as this issue is widespread all over the climatic conditions as a consequence of unsuitable management. The three localities were chosen in South Moravia, Czech Republic, where the vegetation is exposed to unfavorable climatic conditions, relative to the rest of the Czech Republic in sense of drought (very low average annual precipitation causing long-term soil moisture deficit) as well as increased soil loss as the consequence of intensive cultivating and overloading not only arable, but all the farmland. In the Czech Republic, the drought caused by temperature rise, precipitation reduction and unsuitable arable land and forest management is monitored by Intersucho program of the Global Change Institute, Czech Academy of Sciences [81] presenting drought intensity, water deficit, soil moisture saturation, impacts 
on the vegetation, agriculture, and forests [82]. All these localities are founded in exposed areas according to Intersucho models (the actual situation maps are regularly loaded on the program website during the vegetation season) and to real experience of the authors. The average climatic conditions are summarized in Table 1.

The fourth locality was situated it the low mountain area in Žd'árské vrchy with milder climatic conditions than in South Moravia but was included due to its real erosion threat and with an effort to test an irregular shape of the bosk. At each locality, the bosk was planted or seeded and the shape and species composition were designed as suitable as possible in the harmony with the surrounding environment. In the close neighborhood, so-called "comparative feature" was fixed. This vegetation feature has already existed for a longer time, is similar to the new bosks and serves for the soil analyses comparison and as the possible model of these conditions of new bosks after some years, in order of decades.

At the localities, erosion and hydrological conditions analyses were conducted as well as the soil survey and estimation of the soil unit, which are the basis for the bosk space location and its design. Also, the weather stations and sensors for global soil radiation, soil humidity and temperature measurement were installed at the localities. In the first two years after plantation, it was necessary to protect the bosks against the game damage by wire or electric fence and prevent the storm spreading. In the second year, other woody species were planted and seeded. The continuous monitoring of the conditions and development was important, especially in the case of the seeded plants. This case report targets on the ecosystem services evaluation in these four localities, the evaluation was performed in July 2020, approximately one year and a half after the plantation of bosks (spring 2019) and the predicted value after 30 years (state in 2049) was calculated as the HAV methods enables. However, the method does not work with the alternative scenarios-only the default and fully functional habitat.

\subsection{Research Localities}

\subsubsection{Blížkovice}

Vegetation anti-erosion feature is located in the Blížkovice cadastral territory (Znojmo district, South Moravian region, GPS 48.9981883 N, 15.8249519 E). The basic ecological characteristics are described in Table 1 . The bosk consists of two belts with an area of $871 \mathrm{~m}^{2}$, seeded by woody plant mix in the amount of $50 \%, 100 \%$, or $200 \%$ of the recommended seed dosage (e.g., the recommended amount for oak is 35 seeds per one seeding row, etc.) [83]. Sowing is completed by seedlings providing the protective shade. As the comparative feature, the elm alley (The Ent's Path) with grassy herb floor was chosen (Figures 1 and 2c).

Table 1. Basic habitat ecological characteristics applied within Habitat Valuation Method (HAM) [84-86].

\begin{tabular}{cccccc}
\hline Locality & $\begin{array}{c}\text { Altitude } \\
\text { [masl] }\end{array}$ & Vegetation Stage & $\begin{array}{c}\text { Average } \\
\text { Temperature in } \\
\text { January [ }{ }^{\circ} \text { ] }\end{array}$ & $\begin{array}{c}\text { Average } \\
\text { Temperature } \\
\text { in July [ }{ }^{\circ} \text { ] }\end{array}$ & $\begin{array}{c}\text { Average Precipitation } \\
\text { during Vegetation Season } \\
\text { (April-October) [mm] }\end{array}$ \\
\hline Blížkovice & $400-420$ & 3rd oak-beech & $-3-(-4)$ & $17-18$ & $400-500$ \\
Třebelovice & $445-470$ & 3rd-4th oak-beech, beech & $-4-(-5)$ & $16-17$ & $350-450$ \\
Kyjovice & $235-240$ & 1st oak & $-2-(-3)$ & $19-20$ & $300-350$ \\
Kameničky & $667-673$ & 5th fir-beech & $-3-(-4)$ & $15-16$ & $500-600$ \\
\hline
\end{tabular}

\subsubsection{Třebelovice}

This anti-erosion vegetation feature is located in the Třebelovice cadastral territory (Třebíč district, Vysočina region, GPS 49.0137489 N, 15.6559956 E). The basic ecological characteristics are described in Table 1 . The bosk sowing was performed on the borderline of grassy rocky hillock and arable land and its current area is $558 \mathrm{~m}^{2}$ The hillocks are usually drying out habitats (due to the very thin soil cover and protruding rock); however, it is surrounded by less favorable monocultures of agricultural crops, so it provides refuge for animals like small mammals or birds. Amending the grassland of woody species 
generates milder microclimatic conditions (e.g., cooler, and more humid air than in the direct sunlight, shade, or soil moisture evaporation protection) and rises the protective function of this locality. As the comparative feature, the grassy country lane with bird cherries was chosen (Figures 1 and $2 \mathrm{a}, \mathrm{c}$ ).

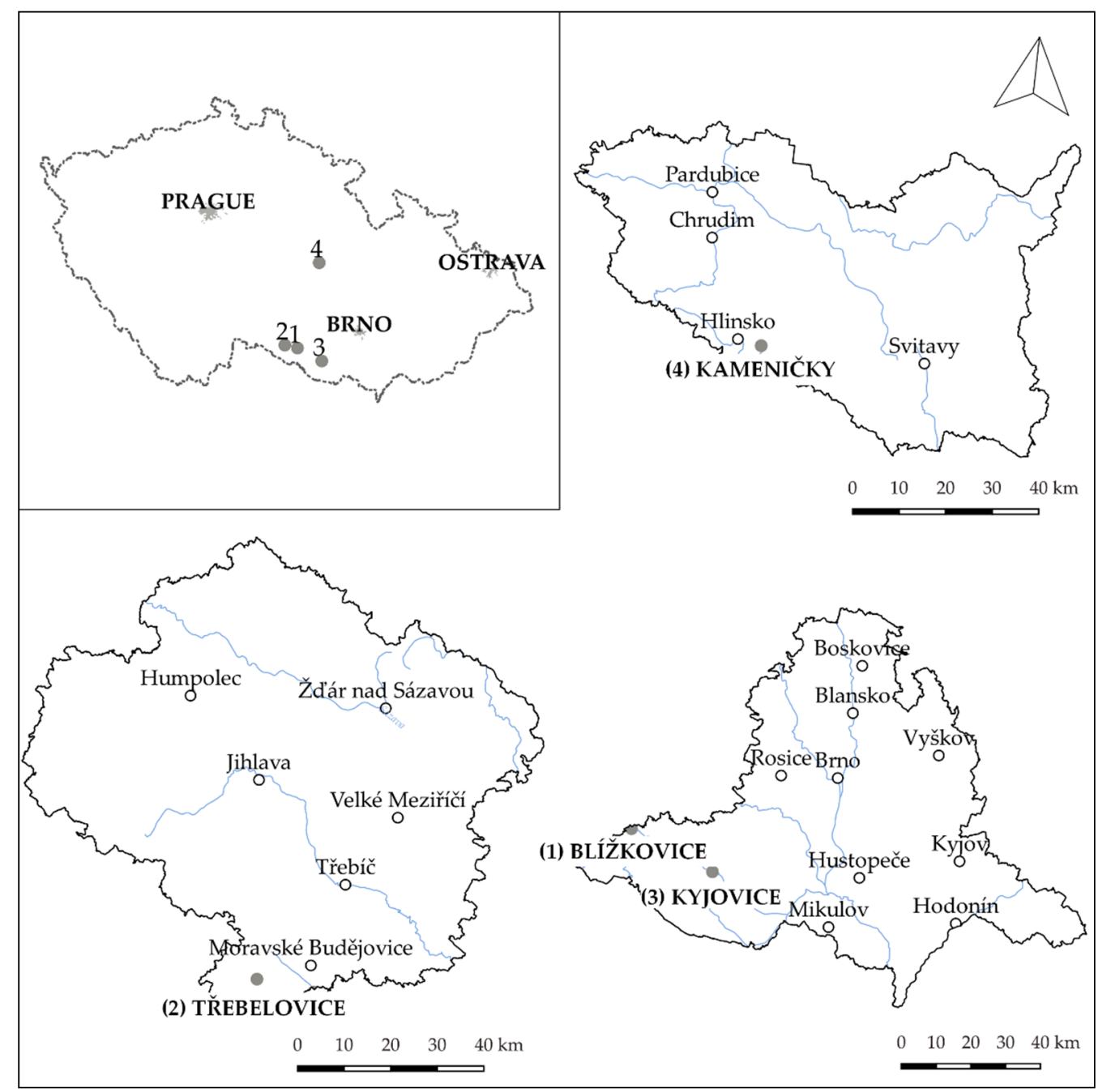

Figure 1. Localization of the four bosks within the Czech Republic.

\subsubsection{Kyjovice}

This anti-erosion vegetation feature is located in the Kyjovice cadastral territory (Znojmo district, South Moravian region, GPS 48.9157114 N, 16.1611172 E). The basic ecological characteristics are described in Table 1. This bosk was implemented like the belts sown with $50 \%, 100 \%$, or $200 \%$ of the recommended seed dosing completed by the seedlings providing shade protection with the total area of $2600 \mathrm{~m}^{2}$. The grassland with woody species on the borderline between arable field and road was chosen as the comparative feature (Figures 1 and $2 b$ ).

At these three localities, the sessile oak (Quercus petraea (Matt.) Liebl.) and bird cherry (Prunus avium L.) were chosen as the target wood species. Also, auxiliary species were planted-hedge maple (Acer campestre L.) and European birch (Betula pendula Roth.) completed with bush trees like common hawthorn (Crataegus monogyna Jacq.), common dogwood (Cornus sanguinea L.), wild privet (Ligustrum vulgare L.) or way-faring tree (Viburnum lantana L.). As the shade providing trees, these species were planted: White mulberry (Morus alba L.), mahaleb cherry (Prunus mahaleb L.), European aspen (Populus tremula L.), hedge maple (Acer campestre L.), and European chestnut (Castanea sativa Mill.). 


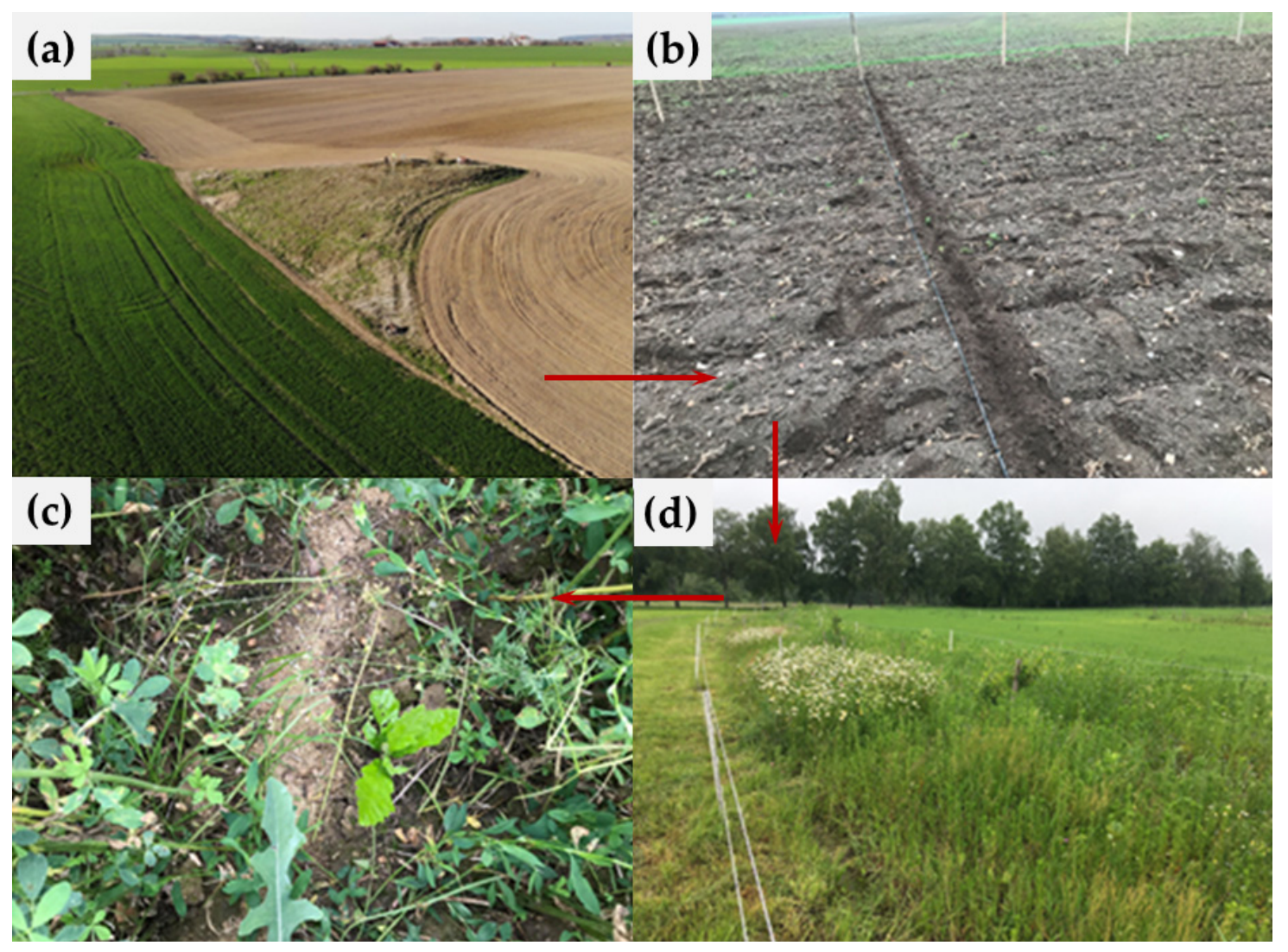

Figure 2. The localities and bosks during the time: (a) Třebelovice—locality before planting, April 2018, (b) Kyjovicesowing row, March 2019; (c) Blížkovice—sessile oak (Quercus petraea (Matt.) Liebl.) seedling, August 2020; (d) Kameničky— lower part of the bosks with blooming meadows, July 2020.

\subsubsection{Kameničky}

This vegetation feature is situated in the Kameničky cadastral territory (Chrudim district, Pardubice region, 49.7547869 N, 15.9782261 E). The basic ecological characteristics are described in Table 1 . The locality in different climatic conditions was included because the erosion is not only an issue within warm areas, but is also related to any farmland, especially the wind erosion is a problem of this region. This bosk was planted thanks to a local farmer, who provided his parcel for this experiment, as the own activity of farmers and education are also some of the project goals. This bosk was planted by pre-grown forest woody species with the combination of useful species, e.g., melliferous mespilus. In some parts, the rich florid meadow mixture of unbred herb and grass species was seeded. In some places the dead wood was left to help rise the organic matter in the soil. This bosk consists of the three particular parts and the total area is $1820 \mathrm{~m}^{2}$. On the surrounding arable land, both common and uncommon crops are grown alternately, for instance barley, buckwheat, bundle, etc. (Figures 1 and 2d).

Woody species there are as follows: Silver fir (Abies alba Mill.), European birch (Betula pendula Roth.), European mountain ash (Sorbus aucuparia L.), black alder (Alnus glutinosa (L.) Gaertn.), green alder (Alnus alnobetula (Ehrh.) C. Koch), European hazel (Corylus avellana L.), midland hawthorn (Crataegus laevigata (Poir.) DC.), wild privet (Ligustrum vulgare L.), European aspen (Populus tremula L.), bird cherry (Prunus padus L.), European beech (Fagus sylvatica L.), European crabapple (Malus sylvestris Mill.), sycamore maple (Acer pseudoplatanus L.), alder buckthorn (Frangula alnus Mill.), alpine currant (Ribes alpinum L.), snowy mespilus (Amelanchier alnifolia (Nutt.) Nutt. ex M. Roem.), and Scotch elm (Ulmus glabra Huds.). 


\subsection{Ecosystem Services Evaluation-Methods}

At the research plots, the ecosystem services evaluation targeted to habitat provision and biodiversity was performed. The Habitat Valuation Method (HVM) [1] which is based on biodiversity assessment was used. It evaluates Habitat services-habitat for species, maintenance of genetic diversity according to TEEB [56,87].

\subsubsection{Description of the Method}

The principle of the HVM origins in the method of ecological harm on habitats assessment used in Hesse (Germany) and was further developed in the Czech Republic. The method is based on the national list of habitat types and their expert valuation using eight biodiversityrelated ecological criteria with assigned point value ranging from 1 to 6 points (Table 2). The relative point value has been calculated for each habitat type of the Czech Republic (related to $1 \mathrm{~m}^{2}$ of the habitat area) representing its relative ecological value in comparison to other habitats. According to this, the first step consisted in choosing a habitat type from the list of typical habitats, its evaluation by 1 to 6 points per 1 square meter for each characteristic and the total calculation of points for all 8 characteristics altogether.

Table 2. Basic habitat ecological characteristics used within Habitat Valuation Method (HVM).

\begin{tabular}{ccc}
\hline No. & Name of Characteristics & Points According to: \\
\hline 1 & Habitat type maturity & Phylogenetic age of formation and species \\
2 & Habitat type nature & 6 pts for natural, 1 pt for anthropogenic habitat type \\
3 & Habitat type structures diversity & 6 pts for all vegetation floors \\
4 & Habitat type species diversity & Number of all naturally present species \\
5 & Habitat type rarity & Geographic and climatic uniqueness, frequency, and area \\
6 & Habitat type species rarity & Number of rare and endangered species \\
7 & Habitat type vulnerability & Vulnerability caused by the habitat conditions change \\
8 & Habitat type threat & Dependence on the human activities change
\end{tabular}

The second step is the individual valuation of particular habitats using the coefficient reducing or increasing the point value from the first step according to the state of that particular habitat (how it differs from a typical habitat type from the list). For natural and seminatural habitats, the six criteria were used to correct the habitat type value, for unnatural habitats (which are at our specific plots), the scale is created for each habitat type and describes three to four levels of the habitat state and their corresponding coefficient values regarding the following criteria:

- The presence and proportion of potential natural vegetation species,

- the presence and proportion of ubiquistic species,

- the presence and proportion of synantropic species,

- the presence and proportion of invasive and expansive species,

- the number of vegetation layers and floors,

- the vegetation cover,

- method and regime of habitat use, and

- intentional application of chemicals or other substances from the activity in the vicinity of the habitat.

The corresponding coefficient can be lower than 1 (means that the real situation is worse than the chosen habitat type), can equal 1 (means that the real situation corresponds to the chosen habitat type) or can be higher than 1 (means that the real situation is better than chosen habitat type). After this adjustment, the total points were gained by multiplying the corrected point amount for $1 \mathrm{~m}^{2}$ by the area of the locality. The more detailed description of the point correction process is included in the HVM [1].

The advantage of this method is the possibility to evaluate the future state of habitats using estimation of vegetation development based on development curves and time necessary to reach the state of full functionality which was estimated for various habitat groups. Thanks to this it was possible to evaluate the hypothetical target state of bosks after 30 years of planting as the third step of the evaluation. 


\subsubsection{Habitat Financial Evaluation}

The financial value of one point has been determined based on economic analysis made for 182 realized restoration projects [1] where an increase in ecological value of habitats in the restored area was calculated by comparison of the state before restoration and the target state after restoration. The value of one point was obtained as a ratio of the total expenses on the project and the total long-term expected point increase. The final monetary value of one point for the Czech Republic was approximately 1.11 EUR in 2018 [1]. This price is based on actual budget investments which were spent by Czech society on specific projects of ecological restoration [1].

\subsubsection{The Use of HVM at the Project Localities}

At each locality, for the state before planting (2019) and their expected economic benefits after 30 years (2049), the habitat type was determined with the corresponding point value from the methodology. After that, the individual valuation was performed. For the state before planting it was determined based on the surrounding area survey (mostly arable land, where the individual value was 1 because the habitat type value did not differ from the typical one). For the target state, it was based on the field survey in the localities with the emphasis on the woody plants species composition: Are there native species corresponding to natural conditions (potential vegetation)? Is there functional differentiation of species (target species and pioneer species)? Are there species of the different growth rate promising development of various vegetation layers? What is the species richness? Are there any non-native trees planted and any unsuitable species chosen? Based on these parameters, the coefficient of the individual valuation, which can range between 1.15 and 1.3 and multiplies the habitat type point value, was determined according to HVM.

The difference between point values for the state before planting and the target state, multiplied by the area, represents a gain of the point value brought by this restoration activity. This gain can be expressed in the monetary term when multiplied by the economic value of one point which has been determined based on analyses of restoration costs and gains as described above.

\section{Results}

In the paragraphs below, the situations of each locality are explained and commented with the emphasis on the comparison of the state after restoration (2020) and the expected state after 30 years, which primarily means the financial benefit of the measurements brought into the land during this period.

\subsection{Habitat Point and Financial Evaluations Results \\ 3.1.1. Blížkovice}

This bosk has too small area $\left(871 \mathrm{~m}^{2}\right)$ and does not keep the requirements for natural habitat development. It can be included in close to nature habitats class according to HVM, as the most suitable class is "woody vegetation on agricultural and other land" with the point value of $20 \mathrm{pts} / \mathrm{m}^{2}$. In frames of individual terrain point evaluation, this value was increased by 1.15 correcting coefficient and finally reached $23 \mathrm{pts} / \mathrm{m}^{2}$. The reason and background for this coefficient choice is providing the development of planted wood species into the stand of suitable species composition with target species (oak, cherry), pioneer species (aspen) and fruit trees (chestnut, walnut). Concurrently, the proportion of such species does not exceed $10 \%$. The original unsown area was included among "weed vegetation of annual and biennial agricultures" habitat with the point value of $9 \mathrm{pts} / \mathrm{m}^{2}$.

After the procedure described above, the supposed financial benefit in the sense of the ecosystem service "environment for the species life providing and genetic diversity conserving" is determined. The value of this ecosystem service within the bosk in Bližkovice reaches the amount of 356,796.00 CZK (13,168.35 EUR/15,497.39 USD) (Figures 3 and 4). 


\section{Ecosystem services increase [EUR]}

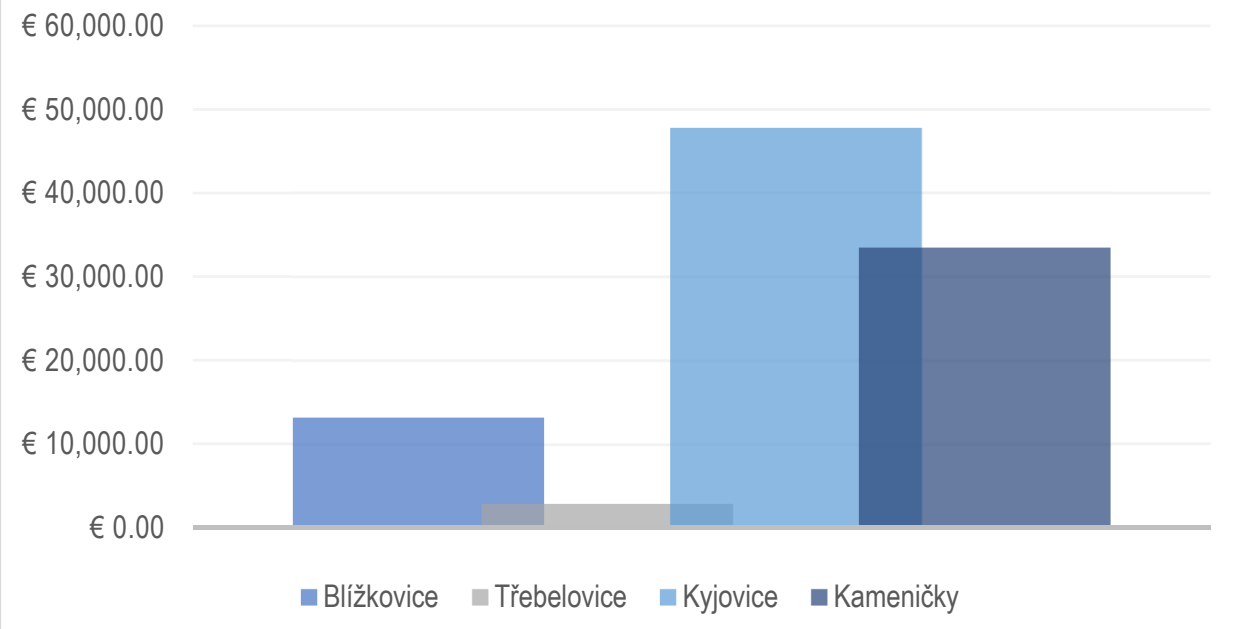

Figure 3. Absolute expected ecosystem services increase within research localities.

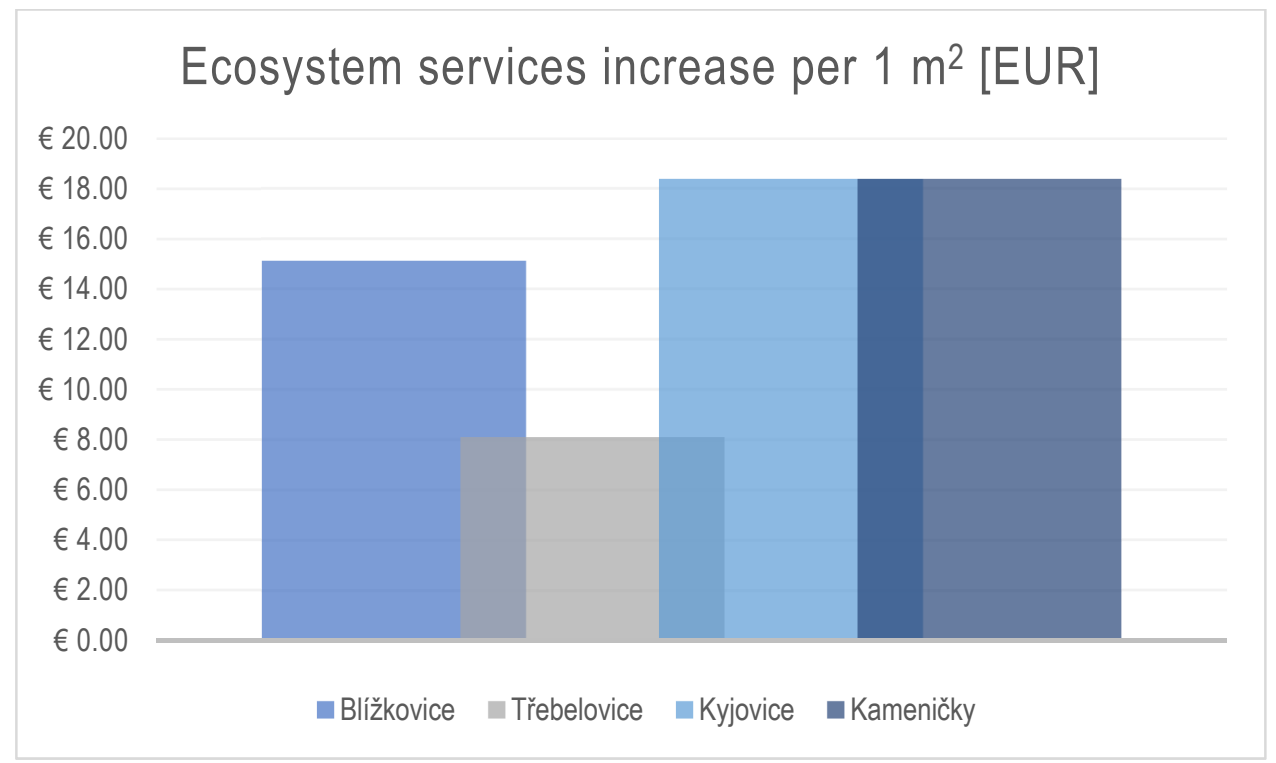

Figure 4. Expected ecosystem services increase per $1 \mathrm{~m}^{2}$ within research localities.

\subsubsection{Třebelovice}

Because of the similar features, this bosk evaluation is equal to the previous one (the area of $558 \mathrm{~m}^{2}$ ). It can also be included into close to nature habitats class "woody vegetation on agricultural and other land" with the point value of $20 \mathrm{pts} / \mathrm{m}^{2}$. During the individual terrain evaluation, the same correcting coefficient of 1.15 was used, so finally the point value reached $23 \mathrm{pts} / \mathrm{m}^{2}$. This can be justified by the woody vegetation floor development with the suitable wood species composition, where the target species are included (oak, cherry) as well as the pioneer species (aspen) and fruit trees (chestnut, walnut, mahaleb, and mulberry). The amount of these species does not exceed $10 \%$. The original area in the upper part was included in "nature-distant dry lawns, hems, and heaths" habitat class with the point value of $23 \mathrm{pts} / \mathrm{m}^{2}$, whereas the lower part belongs to "nature-distant mesophilic meadows, pastures, and fallows" with the point value of $13 \mathrm{pts} / \mathrm{m}^{2}$.

According to the aforementioned method, the amount of 78,417.00 CZK (13,168.35 EUR/15,497.39 USD) expresses the benefit in the sense of the ecosystem service 'environment for the species life providing and genetic diversity conserving' (Figures 3 and 4). 


\subsubsection{Kyjovice}

This bosk is also included into "woody vegetation on agricultural and other land" habitat class with the point value of $20 \mathrm{pts} / \mathrm{m}^{2}$ (the area of $2600 \mathrm{~m}^{2}$ ). The 1.30-correcting coefficient value was chosen, and the point value increased to $26 \mathrm{pts} / \mathrm{m}^{2}$. The reason for such a rise is the wood vegetation floor development in the suitable species composition with long-age (oak) and pioneer (ash) species, that can ensure the growth of many woody vegetation age grades and floors. The original unsown area was included among "weed vegetation of annual and biennial agricultures" habitat with the value of $9 \mathrm{pts} / \mathrm{m}^{2}$.

After the same numeric process as in the case of the previous localities, the amount of 1,296,292.00 CZK (47,731.76 EUR/56,173.90 USD) expresses the benefit in the sense of the ecosystem service "environment for the species life providing and genetic diversity conserving" (Figures 3 and 4).

\subsubsection{Kameničky}

This locality with an area of $1820 \mathrm{~m}^{2}$ also does not meet the conditions for the natural habitat development, so it is included in "weed vegetation of annual and biennial agricultures". The 1.30-correcting coefficient value was chosen, and the point value increased to $26 \mathrm{pts} / \mathrm{m}^{2}$. Justification for this fact is that the suitable wood species composition was chosen as it contains the target species (elm, maple, alder) and pioneer wood (aspen, ash) and bush (hazel, hawthorn) species. The original unsown area was also included in "weed vegetation of annual and biennial agricultures" habitat with the value of $9 \mathrm{pts} / \mathrm{m}^{2}$. According to the methodology, the amount of 905,304.00 CZK (33,412.23 EUR/39,321.74 USD) benefit was calculated in the sense of the ecosystem service "environment for the species life providing and genetic diversity conserving" (Figures 3 and 4).

The total default value of the habitats of the four localities in 2019 was calculated at $1,555,841.92$ CZK $(57,421.74$ EUR/65,571.86 USD) and the target expected value after 30 years was calculated at 4,189,651.62 CZK (154,628.22 EUR/181,960.98 USD). In terms of ecosystem services provision per $1 \mathrm{~m}^{2}$, Třebelovice is the most valuable locality (453.94 CZK), other localities are significantly less valuable (263.34 CZK). The highest target state value is expected in Kyjovice and Kameničky (760.76 CZK) as well as the highest value increase (by $497.42 \mathrm{CZK}$ ). The rather lowest target value is expected in Blížkovice and Třebelovice (497.42 CZK), whereas the increase is 409.64 CZK, resp. 219.04 CZK. In the instance of Třebelovice, distinctly lowest increase is caused by its highest default state value and quite low target state value. Overall, total increase at all project localities is expected to be 2,633,0809.64 CZK $(97,206.48 \mathrm{EUR} / 114,399.06 \mathrm{USD})$, the average increase per $1 \mathrm{~m}^{2}$ is $405.88 \mathrm{CZK}$ (14.98 EUR/17.63 USD) (Table 3, Figures 3 and 4).

Table 3. The summary of total and average values of financial habitat evaluation.

\begin{tabular}{|c|c|c|c|c|c|}
\hline & Blížkovice & Třebelovice & Kyjovice & Kameničky & \\
\hline Area $\left(\mathrm{m}^{2}\right)$ & 871 & 358 & 2600 & 1820 & Total \\
\hline Default value (2019) (CZK) & $229,369.14$ & $162,510.04$ & $684,684.00$ & $479,278.80$ & $1,555,841.98$ \\
\hline Target value (2049) (CZK) & $586,165.58$ & $240,926.84$ & $1,977,976.00$ & $1,384,583.20$ & $4,189,651.62$ \\
\hline Increase $(\mathrm{CZK})$ & $356,796.44$ & $78,416.80$ & $1,293,292.00$ & $905,304.40$ & $2,633,809.64$ \\
\hline$\left(E^{1} R^{1}\right)$ & $13,168.35$ & 2894.14 & $47,731.76$ & $33,412.23$ & $97,206.48$ \\
\hline$\left(\mathrm{USD}^{2}\right)$ & $15,497.39$ & 3406.02 & $56,173.91$ & $39,321.74$ & $\begin{array}{c}\text { 114,399.06 } \\
\text { Average }\end{array}$ \\
\hline Default value $/ 1 \mathrm{~m}^{2}$ & 263.34 & 453.94 & 263.34 & 263.34 & 310.99 \\
\hline Target value/1 m² & 672.98 & 672.98 & 760.76 & 760.76 & 716.87 \\
\hline Increase $/ 1 \mathrm{~m}^{2}(\mathrm{CZK})$ & 409.64 & 219.04 & 497.42 & 497.42 & 405.88 \\
\hline$\left(\mathrm{EUR}^{1}\right)$ & 15.12 & 8.08 & 18.36 & 18.36 & 14.98 \\
\hline$\left(\mathrm{USD}^{2}\right)$ & 17.79 & 9.51 & 21.61 & 21.61 & 17.63 \\
\hline
\end{tabular}

\footnotetext{
${ }^{1}$ Exchange rate: 27.095 CZK/1 EUR; ${ }^{2}$ Exchange rate: 23.025 CZK/1 USD (5 October 2020, Czech National Bank).
} 


\section{Discussion}

All the values mentioned as "target" represent medium- or long-term estimation according to the contemporary state and possible development due to the usual generally known evolution of the similar vegetation features. Expected development of the bosks could be potentially threatened by external factors, which can negatively influence seedlings vitality, e.g., unfavorable weather (ground freezers, drought) [88-90], game damage (browsing by ungulates or hares) [91-94] vole damage on the root system, weeding by reed grass or thistles $[95,96]$. In case of secure failure, the bosks against the damage, the expected value increase could continuously decrease. However, to a certain extent, such damage is a natural process, and it is necessary to count with partial canopy loosening (this fact is taken into account within the evaluation). On the other hand, the ecosystem service value could be maintained or increased by natural reproduction of some species. The value should also be increased by conceiving favorable conditions for other plant species which can appear and the higher concentration of insects, birds (e.g., quail nesting), small game (hare, pheasant) or ungulates (roe deer) is expected. The most important aspect of the project solved within these localities is increasing of anti-erosion endurance of given farmland blocks. This should be reached by gradual improvement of soil particles cohesion or organic matter increase, etc. After the 30-year period, it will be highly suitable to make new evaluation and compare the expectations with future reality. The alternative scenarios are not included because the HVM does not work with them and applying a different method could be the research issue of another study.

Considering the cost-effectiveness of the planted bosks, including protection against game damage, the average final monetary value of one point (approximately $29.60 \mathrm{CZK}-$ 1.11 EUR for the Czech Republic in 2018 [1]—described in Section 2.2.2) can be compared to our real costs needed for 1-point increase of the locality. If all four localities are counted and without human labor cost, this value equals approximately 1 CZK (0.03 EUR/0.04 USD). When human labor is included, the value rises to $1.4 \mathrm{CZK}$ (0.05 EUR/0.06 USD). And if we double this cost, the value remains very low at the value of 2.8 CZK (0.10 EUR/0.12 USD). All the values are far from the average point monetary value based on specific projects of ecological restoration costs. According to this comparison, we can declare very high cost-effectiveness of such vegetation landscape features, despite the possible reduction of their expected value.

\section{Conclusions}

The goal of this paper was to evaluate the value of the seeded and planted bosks using HVM in the sense of the ecosystem service environment for the species life providing and genetic diversity conserving. The evaluation was performed prior to planting and the expected value was also calculated after the 30 -year period. Threats as well as future positive benefits were discussed. The total value of all the localities before planting was calculated at 1,555,841.92 CZK (57,421.74 EUR/65,571.86 USD) and the expected value $4,189,651.62$ CZK (154,628.22 EUR/181,960.98 USD). This means that the benefits gained during 30 years were calculated to be 2,633,809.64 CZK (97,206.48 EUR/114,399.06 USD). Converted to $1 \mathrm{~m}^{2}$, the average value increase for all the localities is $405.88 \mathrm{CZK}$ (14.98 EUR/17.63 USD) and the highest increase is expected in Kyjovice and Kameničky. This evaluation should be made after 30 years with the aim to compare expected and real situations and to gain new knowledge about this specific vegetation landscape feature. It can be stated that such bosks are a very valuable contribution to the ecosystem services provision, by which human can contribute to the development of soil erosion protection and the diversity of the landscape as a whole.

Author Contributions: Conceptualization, M.B. and L.K.; methodology, M.B., P.S., and M.P.; software, M.B.; validation, M.P., A.B., and P.S.; formal analysis, L.K.; investigation, M.P.; resources, L.K. and M.B.; data curation, P.S. and M.P.; writing-original draft preparation, M.B. and L.K.; writing-review and editing, L.K. and A.B.; visualization, M.B.; supervision, L.K. and A.B.; project administration, 
M.B and P.S.; funding acquisition, M.B. and P.S. All authors have read and agreed to the published version of the manuscript.

Funding: This research was funded by Technology Agency of the Czech Republic, grant number TJ02000265 and the APC was funded by Technology Agency of the Czech Republic, grant number TJ02000265.

Institutional Review Board Statement: Not applicable.

Informed Consent Statement: Not applicable.

Data Availability Statement: Data supporting results: https://www.ldf.mendelu.cz/wcd/web-ldf/ projektove/balkova/tj02000265_hodnocenekosystmovchslueb.pdf.

Acknowledgments: Our thanks also belong to Bc. Sarah Stambolidisová and Bc. Miroslav Šlachetka for their kind help with laboratory analyses.

Conflicts of Interest: The authors declare no conflict of interest. The funders had no role in the design of the study; in the collection, analyses, or interpretation of data; in the writing of the manuscript, or in the decision to publish the results.

\section{References}

1. Seják, J.; Cudlín, P.; Petříček, V.; Prokopová, M.; Cudlín, O.; Holcová, D.; Kaprová, K.; Melichar, J.; Škarková, P.; Žákovská, K.; et al. Metodika hodnocení biotopu (6. verze). (Habitat Valuation Method); Nature Conservation Agency of the Czech Republic: Praha, Czech, 2018. (In Czech)

2. Alberti, M.; Marzluff, J.M. Ecological resilience in urban ecosystems: Linking urban patterns to human and ecological functions. Urban Ecosyst. 2004, 7, 241-265. [CrossRef]

3. Jackson, L.E.; Pascual, U.; Hodgkin, T. Utilizing and conserving agrobiodiversity in agricultural landscapes. Agric. Ecosyst. Environ. 2007, 121, 196-210. [CrossRef]

4. Schwartz, M.W.; Brigham, C.A.; Hoeksema, J.D.; Lyons, K.G.; Mills, M.H.; Van Mantgem, P.J. Linking biodiversity to ecosystem function: Implications for conservation ecology. Oecologia 2000, 122, 297-305. [CrossRef] [PubMed]

5. Jongman, R.H. Homogenisation and fragmentation of the European landscape: Ecological consequences and solutions. Landsc. Urban Plan. 2002, 58, 211-221. [CrossRef]

6. Scherr, S.J.; Satya, N.Y. Land Degradation in the Developing World: Implications for Food, Agriculture, and the Environment to 2020; 2020 Vision Discussion Papers 14; International Food Policy Research Institute (IFPRI): Washington, DC, USA, 1996; No. 584-2016-39743.

7. Firbank, L.G.; Petit, S.; Smart, S.; Blain, A.; Fuller, R.J. Assessing the impacts of agricultural intensification on biodiversity: A British perspective. Philos. Trans. R. Soc. B 2008, 363, 777-787. [CrossRef] [PubMed]

8. Arnold, S.; Williams, E.R. Quantification of the inevitable: The influence of soil macrofauna on soil water movement in rehabilitated open-cut mined lands. Soil 2016, 2, 41-48. [CrossRef]

9. Reinecke, S.; Reinecke, A. The impact of organophosphate pesticides in orchards on earthworms in the Western Cape, South Africa. Ecotoxicol. Env. Safety. 2007, 66, 244-251. [CrossRef]

10. Bruun, T.B.; Elberling, B.; de Neergaard, A.; Magid, J. Organic carbon dynamics in different soil types after conversion of forest to agriculture. Land Degrad Devel. 2015, 26, 272-283. [CrossRef]

11. Quinton, J.N.; Govers, G.; Van Oost, K.; Bardgett, R.D. The impact of agricultural soil erosion on biogeochemical cycling. Nat. Geosci. 2010, 3, 311-314. [CrossRef]

12. Karásek, P.; Konečná, J.; Pochop, M.; Kučera, J.; Podhrázská, J. Priority Areas for Initiating Land Consolidations Related to Erosion and Water Retention in the Landscape, Czech Republic. J. Ecol. Eng. 2018, 19, 16-28. [CrossRef]

13. Khan, M.N.; Mobin, M.; Abbas, Z.K.; Alamri, S.A. Fertilizers and their contaminants in soils, surface and groundwater. Encycl. Anthr. 2018, 5, 225-240.

14. Salem, M.A.; Bedade, D.K.; Al-Ethawi, L.; Al-Waleed, S.M. Assessment of physiochemical properties and concentration of heavy metals in agricultural soils fertilized with chemical fertilizers. Heliyon 2020, 6, e05224. [CrossRef] [PubMed]

15. Mohamed, E.; Belal, A.; Ali, R.R.; Saleh, A. Land Degradation. The Soils of Egypt; Springer: Cham, Switzerland, 2019; pp. 159-174.

16. Borrelli, P.; Robinson, D.A.; Panagos, P.; Lugato, E.; Yang, J.E.; Alewell, C.; Wuepper, D.; Montanarella, L.; Ballabio, C. Land use and climate change impacts on global soil erosion by water (2015-2070). Proc. Natl. Acad. Sci. USA 2020, 117, 21994-22001. [CrossRef] [PubMed]

17. Šarapatka, B.; Alvarado-Solano, D.P.; Čižmár, D. Can glomalin content be used as an indicator for erosion damage to soil and related changes in organic matter characteristics and nutrients? Catena 2019, 181, 104078. [CrossRef]

18. Zachar, D. Soil Erosion; Elsevier: Amsterdam, The Netherlands, 2011.

19. Majerová, V. The changing role of agriculture in the Czech countryside. Eur. Green Ring 2017, 89-106.

20. Banski, J. Phases to the transformation of agriculture in Central Europe-Selected processes and their results. Agric. Econ. 2018, 64, 546-553. [CrossRef] 
21. Obalum, S.E.; Chibuike, G.U.; Peth, S.; Ouyang, Y. Soil organic matter as sole indicator of soil degradation. Environ. Monit. Assess. 2017, 189, 176. [CrossRef]

22. Crews, T.E.; Rumsey, B.E. What agriculture can learn from native ecosystems in building soil organic matter: A review. Sustainability 2017, 9, 578. [CrossRef]

23. Cerdà, A.; Doerr, S.H. Soil wettability, runoff and erodibility of major dry-Mediterranean land use types on calcareous soils. Hydrol. Process. 2007, 21, 2325-2336. [CrossRef]

24. Novara, A.; Rühl, J.; La Mantia, T.; Gristina, L.; La Bella, S.; Tuttolomondo, T. Litter contribution to soil organic carbon in the processes of agriculture abandon. Solid Earth. 2015, 6, 425-432. [CrossRef]

25. Janovská, V.; Šímová, P.; Vlasák, J.; Sklenička, P. Factors affecting farm size on the European level and the national level of the Czech Republic. Agric. Econ. 2017, 63, 1-12.

26. Wilhite, D.; Pulwarty, R.S. (Eds.) Drought and Water Crises: Integrating Science, Management, and Policy; CRC Press: Boca Raton, FL, USA, 2017.

27. Trnka, M.; Brázdil, R.; Vizina, A.; Dobrovolný, P.; Mikšovský, j.; Štěpánek, P.; Hlavinka, P.; Řezníčková, L.; Žalud, Z. Droughts and Drought Management in the Czech Republic in a Changing Climate. In Drought and Water Crises, 2nd ed.; Wilhite, D.A., Pulwarty, R.S., Eds.; Integrating Science, Management, and Policy; CRC Press: Boca Raton, FL, USA; Taylor \& Francis: Abingdon, Milton Park, UK, 2017; pp. 461-480. ISBN 978-1-138-03564-5.

28. Shrestha, S.; Sattar, H.; Khattak, M.S.; Wang, G.; Babur, M. Evaluation of adaptation options for reducing soil erosion due to climate change in the Swat River Basin of Pakistan. Ecol. Eng. 2020, 158, 106017. [CrossRef]

29. Prosdocimi, M.; Jordán, A.; Tarolli, P.; Keesstra, S.; Novara, A.; Cerdà, A. The immediate effectiveness of barley straw mulch in reducing soil erodibility and surface runoff generation in Mediterranean vineyards. Sci. Total Environ. 2016, 547, 323-330. [CrossRef] [PubMed]

30. Keesstra, S.; Pereira, P.; Novara, A.; Brevik, E.C.; Azorin-Molina, C.; Parras-Alcántara, L.; Jordán, A.; Cerdà, A. Effects of soil management techniques on soil water erosion in apricot orchards. Sci. Total Environ. 2016, 551, 357-366. [CrossRef]

31. Cudlín, O.; Pechanec, V.; Purkyt, J.; Štěrbová, L.; Cudlín, P. Hodnocení biotopů zemědělsko-lesní krajiny v souvislosti se změnou klimatu pomocí modelů a GIS nástrojů. Ochr. Př́rody 2017, 1, 20-25. (In Czech)

32. Horák, I. The Environmental Goods in Agriculture in the Region of South Moravia and Their Economic Evaluation. In Proceedings of the European Scientific Conference of Doctoral Students, Brno, Czech Republic, 26 November 2020; p. 67.

33. Schneider, J.; Kalasová, Ž.; Fialová, J. Ecosystem Services and Disservices of Watercourses and Water Areas. Assessment and Protection of Water Resources in the Czech Republic; Springer: Cham, Switzerland, 2020; pp. 337-356.

34. Machar, I.; Kulhavý, J.; Seják, J.; Pechanec, V. Conservation effectiveness and monetary value of floodplain forests habitats in the Czech Republic. Zprávy Lesn. Výzkumu 2018, 63, 206-213. (In Czech)

35. Bulǐr, P.; Škorpík, M. Rozptýlená zeleň; Výzkumný ústav okrasného zahradnictví: Praha-Průhonice, Czech Republic, 1987. (In Czech)

36. Lipský, Z. The changing face of the Czech rural landscape. Landsc. Urban Plan. 1995, 31, 39-45. [CrossRef]

37. Marada, P. Zvyšováni Přírodní Hodnoty Polních Honiteb (Natural Value of Arable Land Hunting Grounds Increase); Grada: Prague, Czech Republic, 2011; p. 156. ISBN 978-80-247-3885-7. (In Czech)

38. Koroptvičky. Available online: https://www.koroptvicky.cz/clanky/vyzkum/znamy-nebo-spise-neznamy-remizek-.html (accessed on 3 October 2020). (In Czech).

39. Zákon č. 449/2001 Sb. o myslivosti. Parlament České republiky (Act No. 449/2001 Coll. Game Management, Parliament of the Czech Republic). Available online: https:/ / www.zakonyprolidi.cz/cs/2001-449 (accessed on 18 November 2020). (In Czech).

40. Burel, F.; Baudry, J. Structural dynamic of a hedgerow network landscape in Brittany France. Landsc. Ecol. 1990, 4, 197-210. [CrossRef]

41. Oreszczyn, S.; Lane, A. The meaning of hedgerows in the English landscape: Different stakeholder perspectives and the implications for future hedge management. J. Environ. Manag. 2000, 60, 101-118. [CrossRef]

42. Nařízení vlády č. 307/2014 Sb. Vláda České republiky (Government Decree No. 307/2014 Coll. Government of the Czech Republic). Available online: https:/ / www.zakonyprolidi.cz/cs/2014-307 (accessed on 18 November 2020). (In Czech).

43. Zákon č. 114/1992 Sb. o ochraně přírody a krajiny. Parlament České republiky (Act No. 114/1992 Coll. Nature and Landscape Protection, Parliament of the Czech Republic). Available online: https:/ / www.zakonyprolidi.cz/cs/1992-114 (accessed on 18 November 2020). (In Czech).

44. European Regional Development Fund. Available online: https://ec.europa.eu/regional_policy/en/funding/erdf/ (accessed on 3 January 2021).

45. European Agricultural Fund for Rural Development. Available online: https:/ /ec.europa.eu/info/food-farming-fisheries/keypolicies/common-agricultural-policy/rural-development_en (accessed on 3 January 2021).

46. Program péče o krajinu (Landscape Care Program). Ministry of the Environment of the Czech Republic. Available online: https:/ / www.mzp.cz/cz/program_pece_o_krajinu (accessed on 3 January 2021). (In Czech).

47. Podpora Obnovy Přirozených Funkcí Krajiny (The Landscape Natural Function Restoration Program). Ministry of the Environment of the Czech Republic. Available online: https:/ / www.mzp.cz/cz/podpora_obnovy_prirozenych_funkci_krajiny (accessed on 3 January 2021). (In Czech).

48. MEA-Millenium Ecosystem Assessment Ecosystems and Human Well-being: Synthesis; Island Press: Washington, DC, USA, 2005. 
49. Costanza, R.; d’Arge, R.; de Groot, R.; Farber, S.; Grasso, M.; Hannon, B.; Limburg, K.; Naeem, S.; O’Neill, R.V.; Paruelo, J.; et al. The value of the world's ecosystem services and natural capital. Nature 1997, 387, 253-260. [CrossRef]

50. Daily, G.C. Nature's Services. Societal Dependence on Natural Ecosystems; Island Press: Washington, DC, USA, 1997.

51. Odum, H.T.; Odum, E.P. The Energetic Basis for Valuation of Ecosystem Services. Ecosystems 2000, 3, 21-23. [CrossRef]

52. Braat, L.C.; de Groot, R. The ecosystem services agenda: Bridging the worlds of natural science and economics, conservation and development, and public and private policy. Ecosyst. Serv. 2012, 1, 4-15. [CrossRef]

53. Liu, S.; Costanza, R.; Farber, S.; Troy, A. Valuing Ecosystem Services: Theory, Practice, and the Need for a Transdisciplinary Synthesis. Ann. Ny. Acad. Sci. 2010, 1185, 54-78. [CrossRef] [PubMed]

54. Burkhard, B.; Maes, J. Mapping Ecosystem Services; Pensoft Publishers: Sofia, Bulgaria, 2017; ISBN 978-954-642-830-1.

55. Jacobs, S.; Dendoncker, N.; Keune, H. (Eds.) Ecosystem Services: Global Issues, Local Practices; Elsevier Inc.: Amsterdam, The Netherlands, 2014; ISBN 978-0-12-419964-4.

56. TEEB Mainstreaming the Economics of Nature: A Synthesis of the Approach, Conclusions and Recommendations of TEEB; Progress Press: Mriehel, Malta, 2010; ISBN 978-3-9813410-3-4.

57. Boerema, A.; Rebelo, A.J.; Bodi, M.B.; Esler, K.J.; Meire, P. Are ecosystem services adequately quantified? J. Appl. Ecol. 2017, 54, 358-370. [CrossRef]

58. De Groot, R.S.; de Alkemade, R.; Braat, L.; Hein, L.; Willemen, L. Challenges in integrating the concept of ecosystem services and values in landscape planning, management and decision making. Ecol. Complex 2010, 7, 260-272. [CrossRef]

59. Bouwma, I.; Schleyer, C.; Primmer, E.; Winkler, K.J.; Berry, P.; Young, J.; Carmen, E.; Špulerová, J.; Bezák, P.; Preda, E.; et al. Adoption of the ecosystem services concept in EU policies. Ecosyst. Serv. 2018, 29, 213-222. [CrossRef]

60. Wallace, K.J. Classification of ecosystem services: Problems and solutions. Biol. Conserv. 2017, 139, 235-246. [CrossRef]

61. Costanza, R. Ecosystem services: Multiple classification systems are needed. Biol. Conserv. 2008, 141, 350-352. [CrossRef]

62. La Notte, A.; D'Amato, D.; Mäkinen, H.; Paracchini, M.L.; Liquete, C.; Egoh, B.; Geneletti, D.; Crossman, N.D. Ecosystem services classification: A systems ecology perspective of the cascade framework. Ecol. Indic. 2017, 74, 392-402. [CrossRef]

63. Costanza, R.; de Groot, R.; Braat, L.; Kubiszewski, I.; Fioramonti, L.; Sutton, P.; Farber, S.; Grasso, M. Twenty years of ecosystem services: How far have we come and how far do we still need to go? Ecosyst. Serv. 2017, 28, 1-16. [CrossRef]

64. Van Oudenhoven, A.P.E. 'Mind the Gap' between ecosystem services classification and strategic decision making. Ecosyst. Serv. 2018, 33, 77-88. [CrossRef]

65. Burkhard, B.; Crossman, N.; Nedkov, S.; Petz, K.; Alekmade, R.L. Mapping and modelling ecosystem services for science, policy and practice. Ecosyst. Serv. 2013, 4, 1-3. [CrossRef]

66. European Environmental Agency. Common International Classification of Ecosystem Services V5.1. Available online: https: / / cices.eu/resources / (accessed on 18 October 2020).

67. Frélichová, J.; Vačkář, D.; Pártl, A.; Loučková, B.; Harmáčková, Z.; Lorencová, E. Integrated assessment of ecosystem services in the Czech Republic. Ecosyst. Serv. 2014, 8, 110-117. [CrossRef]

68. Vačkář, D.; Frélichová, J.; Lorencová, E.; Pártl, A.; Harmáčková, Z.; Loučková, B. Metodologický Rámec Integrovaného Hodnocení Ekosystémových Služeb v České Republice. (Methodological Framework of Integrated Assessment of Ecosystem Services in the Czech Republic); Global Change Research Institute of Czech Academy Sciences: České Budějovice, Czech Republic, 2014; (methodology for Ministry of the Environment of the Czech Republic, In Czech).

69. De Groot, R.S.; Wilson, M.A.; Boumans, R.M.J. A typology for the classification, description and valuation of ecosystem functions, goods and services. Ecol. Econ. 2002, 41, 393-408. [CrossRef]

70. Van der Meulen, E.S.; Braat, L.C.; Brils, J.M. Abiotic flows should be inherent part of ecosystem services classification. Ecosyst. Serv. 2016, 19, 1-5. [CrossRef]

71. Van Ree, C.C.D.F.; van Beukering, P.J.H. Geosystem services: A concept in support of sustainable development of the subsurface. Ecosyst. Serv. 2016, 20, 30-36. [CrossRef]

72. Van Ree, C.C.D.F.; van Beukering, P.J.H.; Boekestijn, J. Geosystem services: A hidden link in ecosystem management. Ecosyst. Serv. 2017, 26, 58-69. [CrossRef]

73. Stålhammar, S.; Pedersen, E. Recreational cultural ecosystem services: How do people describe the value? Ecosyst. Serv. 2017, 26, 1-9.

74. Milcu, A.I.; Hanspach, J.; Abson, D.; Fischer, J. Cultural ecosystem services: A literature review and prospects for future research. Ecol. Soc. 2013, 18, 44. [CrossRef]

75. Cooper, N.; Brady, E.; Steen, H.; Bryce, R. Aesthetic and spiritual values of ecosystems: Recognising the ontological and axiological plurality of cultural ecosystem 'services'. Ecosyst. Serv. 2013, 21, 218-229. [CrossRef]

76. Hernández-Morcillo, M.; Plieninger, T.; Bieling, C. An empirical review of cultural ecosystem service indicators. Ecol. Indic 2013, 29, 434-444. [CrossRef]

77. Small, N.; Munday, M.; Durance, I. The challenge of valuing ecosystem services that have no material benefits. Glob. Environ. Chang. 2017, 44, 57-67. [CrossRef]

78. Fish, R.; Church, A.; Winter, M. Conceptualising cultural ecosystem services: A novel framework for research and critical engagement. Ecosyst. Serv. 2016, 21, 208-217. [CrossRef]

79. Bryce, R.; Irvine, K.N.; Church, A.; Fish, R.; Ranger, S.; Kenterf, J.O. Subjective well-being indicators for large-scale assessment of cultural ecosystem services. Ecosyst. Serv. 2016, 21, 258-269. [CrossRef] 
80. FAO Cultural Ecosystem Services. Available online: http://www.fao.org/ecosystem-services-biodiversity/background/culturalservices/en/ (accessed on 18 October 2018).

81. Trnka, M.; Hlavinka, P.; Možný, M.; Semerádová, D.; Štěpánek, P.; Balek, J.; Farda, A. Czech Drought Monitor System for Monitoring and Forecasting Agricultural Drought and Drought Impacts. Int. J. Clim. 2020, 40, 5941-5958. [CrossRef]

82. Intersucho. Global Change Institute, Czech Academy of Sciences. Available online: https:/ /www.intersucho.cz/en/?from=2020 -12-06\&to=2021-01-03\&current=2020-12-27 (accessed on 3 January 2021).

83. Walter, V. Rozmnožování Okrasných Stromů a Keřu (Reproduction of Ornamental Trees and Shrubs); Praha: Státní zemědělské nakladatelství, Czech Republic, 1978. (In Czech)

84. Digital Terrain Model of the Czech Republic of the 5th Generation; State Administration of Land Surveying and Cadastre: Prague, Czech Republic, 2013.

85. Geoportal ÚHUL. Forest Management Institute Information on Czech Forests. Available online: http://geoportal.uhul.cz/mapy/ MapyOprl.html (accessed on 20 October 2020).

86. Quitt, E. Klimatické Oblasti Československa. (Climatic Regions of Czechoslovakia); Academia, Studia geographica: Prague, Czech Republic, 1971; p. 16. (In Czech)

87. Brouwer, R.; Brander, L.; Kuik, O.; Papyrakis, E.; Bateman, I. A synthesis of Approaches to Assess and Value Ecosystem Services in the EU in the Context of TEEB. TEEB Follow-Up Study for Europe; Final Report; University of Amsterdam: Amsterdam, The Netherlands, 2013.

88. Luoranen, J.; Saksa, T.; Lappi, J. Seedling, planting site and weather factors affecting the success of autumn plantings in Norway spruce and Scots pine seedlings. For. Ecol. Manag. 2018, 41, 79-90. [CrossRef]

89. Bolte, A.; Czajkowski, T.; Cocozza, C.; Tognetti, R.; De Miguel, M.; Pšidová, E.; Ditmarová, Ĺ.; Dinca, L.; Delzon, S.; Cochard, H.; et al. Desiccation and mortality dynamics in seedlings of different European beech (Fagus sylvatica L.) populations under extreme drought conditions. Front. Plant Sci. 2016, 7, 751. [CrossRef]

90. Kong, R.S.; Henry, H.A.L. Cross acclimation effects of spring freezing and summer drought on plant functional groups and ecosystem properties. Environ. Exp. Bot. 2019, 164, 52-57. [CrossRef]

91. Drexhage, M.; Colin, F. Effects of browsing on shoots and roots of naturally regenerated sessile oak seedlings. Ann. For. Sci. 2003, 60, 173-178. [CrossRef]

92. Tremblay, J.P.; Huot, J.; Potvin, F. Density-related effects of deer browsing on the regeneration dynamics of boreal forests. J. Appl. Ecol. 2007, 44.3, 552-562. [CrossRef]

93. Redick, C.H.; McKenna, J.R.; Carlson, D.E.; Jenkins, M.A.; Jacobs, D.F. Silviculture at establishment of hardwood plantations is relatively ineffective in the presence of deer browsing. For. Ecol. Manag. 2020, 474, 118-339. [CrossRef]

94. Komonen, A.; Paananen, E.; Elo, M.; Valkonen, S. Browsing hinders the regeneration of broadleaved trees in uneven-aged forest management in southern Finland. Scand. J. For. Res. 2020, 35, 1-5.

95. Debortoli, L.A.; Pinno, B.D.; MacKenzie, M.D.; Li, E.H. Plant community composition and tree seedling establishment in response to seeding and weeding treatments on different reclamation cover soils. Can. J. For. Res. 2019, 49.7, 836-843. [CrossRef]

96. Brus, J.; Deutscher, J.; Bajer, A.; Kupec, P.; Olišarová, L. Monetary assessment of restored habitats as a support tool for sustainable landscape management in lowland cultural landscapes. Sustainability 2020, 12, 1341. [CrossRef] 